\title{
Archaeologies of the recent and contemporary past in Africa
}

Rachel King ${ }^{1,2}$

${ }^{1}$ Institute of Archaeology, University College London

${ }^{2}$ Rock Art Research Institute, University of the Witwatersrand

Corresponding address:

Institute of Archaeology

University College London

31-34 Gordon Square

London WC1H OPY

United Kingdom

tcrnkri@ucl.ac.uk

Summary (150-300 words)

Archaeologies of the recent and contemporary world represent a relatively young movement within Africa. This article reviews the small but growing body of literature in this sub-field both to highlight a moment of disciplinary innovation, and to reflect on what modifications of methodology, ethics, and theory are necessary to adapt an intellectual movement developed in other parts of the world for the African continent. Themes such as time, materiality, and reflexivity are considered in contexts across the continent, as well as where archaeologies of the contemporary world overlap or exist in tension with related moves in cognate African Studies fields.

Keywords (5-10)

Archaeology, contemporary world, recent past, Africa, ethnography, ethnoarchaeology, methods 


\section{Introduction}

Reviewing the archaeology of the recent and contemporary past in Africa is simultaneously unwieldy and straightforward: once one gets past the question of how to define what counts as 'recent' (how do we distinguish this from the historical? Is it a matter of finding the right year or is it based on particular social, political, or economic processes?), the body of scholarship that readily identifies itself as concerned with Africa's recent and contemporary archaeology is vanishingly small. In part, this is due to the relative youth of the contemporary past (or 'the contemporary world', as many proponents and practitioners now prefer) as a sub-field that emerged elsewhere in the world within the last 20 years, and which has spread to Africanist archaeology somewhat haltingly. This sub-field also resonates, intersects, or overlaps with other currents within archaeology that have been more active and more entrenched on the African continent: ethnoarchaeology, heritage studies, public and community archaeology, archaeologies of mercantilism and capitalism, archaeologies of African history, and historical archaeology (these two last two are not synonymous; see Stahl, 2009; King, 2017). Given these factors, then, are we witnessing the establishment of a new stream of thought about the past within Africa, a transformation of the discipline of Africanist archaeology, or a challenge to existing lines of thought?

In its inception, the archaeology of the recent and contemporary world was not foremost concerned with African experiences. While the sub-field developed along different lines in Spain, France, the Nordic countries, Latin America, the United States, and the United Kingdom, there is currently a suggestion that defining the contemporary as a specific chronological period is not the main point of the movement (Harrison and Breithoff, 2017: 204), although some acknowledge that in order to expand the concept more globally 'contemporary' may need redefinition to accommodate local sensibilities 
(González-Ruibal, 2018). Rather than being conceived as relative to a particular chronology, this movement is often characterised foremost as concerned with investigating the practice of archaeology itself, especially its politics and its understanding of time.

Particularly illustrative of this focus on archaeological self-reflection is a preoccupation with ruination and abandonment. Not only are ruins fertile ground for exploring the (literal and theoretical) foundations of a modern world built on an illusion of distance from the past (Dawdy, 2010; Olsen and Pétursdóttir, 2014), but archaeologists' focus on ruins is taken to illustrate a need to critique their preoccupation with places that appear defunct or dead and thus distinct from the living and the future (Graves-Brown et al., 2013, 6; cf. Harrison, 2011). This sort of self-criticism of dispositions towards ruination - as well as toward other themes such as time, modernity, conflict, and popular culture - has prompted assertions that the archaeology of the contemporary world is an 'archaeology of us' (compare Gould and Schiffer, 1981 with more recent interventions, Buchli and Lucas, 2001: 8, Harrison and Schofield, 2010: 12). This formulation is intended to suggest a productive estrangement: if one accepts that archaeology's practices create the past as a distant and foreign country, then giving the present the same treatment makes the familiar look 'uncanny' and introduces new perspectives on human relationships to the material world (Graves-Brown, 2000; Hicks, 2010). The notion of an 'archaeology of us' has been critiqued for the voices that it privileges (who are the 'us' referred to and how did they come to be at the centre of analysis?) and those that it excludes, as well as the methods used for investigating this proposition (Fewster, 2013). 
Applying the archaeology of the contemporary world to the African continent thus requires modification and raises some questions about the methodological and theoretical corollaries of the sub-field's approaches to African contexts. Especially problematic is the 'archaeology of us' position, given how much archaeology on the continent is still carried out by Western researchers and how much of the scholarship on African contemporary archaeology has been conducted by this same demographic. Investigations of, for instance, the traces of recent international development interventions and missionary efforts may be related more closely to the Western 'us'. However, this 'us' seems unavoidably to produce a 'them' that is redolent of the sorts of anthropological and archaeological projects that rendered African communities (past and present) as inescapably Other. Africanist ethnoarchaeology has arguably spent more time critiquing this position. Relatedly, the suggestion that the archaeology of the contemporary world can usefully render the present uncanny harkens back to characterisations of Africa as exotic and existing in its own time, accessible to (Western) experts and explorers in the Orientalist manner described by Edward Said.

Further questions about the role of the archaeology of the contemporary world in Africa relate to the methods and sources claimed by the sub-field. These can include ethnography, oral history, archival studies, and material culture studies (Harrison and Breithoff, 2017), all of which have particular histories of practice and disciplinary traditions on the continent.

Additionally, and as mentioned above, several archaeological sub-disciplines and related fields have long been preoccupied with the relationships between past and present in Africa. Ethnoarchaeology's concern with how insights develop from presentday (typically indigenous) communities provides insights into understandings of 
material culture both now and in the past. Heritage studies fundamentally focused on the role of the past in the present - whether as a tangible object, discourse, commodity, or something else - have produced a veritable wave of scholarship from archaeology, history, anthropology, art history, and other fields over the past few decades (see, e.g., Fouéré and Hughes, 2015; Peterson et al., 2015). Both heritage studies and public or community archaeology have foregrounded the centrality of disciplinary self-reflection in articulating what archaeology can do in modern Africa, in terms of providing 'usable' information to support peoples' livelihoods and illuminating lived experiences that had gone unnoticed under earlier disciplinary paradigms (e.g. the archaeology and heritage of urban spaces and of diasporic communities, Mire, 2007; Weiss, 2014) (e.g. Chirikure et al., 2010; Schmidt and Pikirayi, 2016). Archaeologies of the 'modern world' in Africa have focused on the spread of global mercantilism (supporting global slavery and colonialism) not as bygone periods or finished projects but as on-going processes (Croucher and Weiss, 2011; Lane and MacDonald, 2011; Monroe and Ogundiran, 2012); in this, these perspectives resonate with those of historians and anthropologists who have long suggested that we reject the idea of distinct ruptures separating precolonial, colonial, and post-colonial present. Within anthropology, popular culture studies similarly reject a hard division between traditional and modern, and examine how diverse genres engage with different conceptions of time and materiality.

Given the affordances and limitations of the archaeology of the recent and contemporary past just described, what does the adoption of this perspective offer on the African continent? For the moment, and given that this strand of thought is still young in Africa, it is worth taking this as an opportunity to examine the methodological and theoretical issues or adaptations raised by introducing the sub-field to a new context with strong, longstanding disciplinary traditions. Does this reveal anything about how 
archaeology works and produces knowledge in Africa? As just mentioned, this discussion captures a moment in the life of a sub-discipline that is still nascent in its African application (it is arguably well-established at this point in Europe and the Americas). As such, what is offered here is as much a review as a sort of trend analysis exercise - what does it mean that the archaeology of the contemporary world is being considered in an African context and what would this look like if it becomes entrenched? Perhaps this kind of self-reflection is exactly what contemporary archaeology's interlocutors had in mind to begin with.

\section{Orientations and methods for archaeologies of the contemporary past in Africa}

Before delving into the sources and methods relevant to archaeologies of the contemporary world in Africa, it is worth considering some of the major analytical concerns underpinning the uses of these sources. Understanding these orientations clarifies the selection of methodological tools that scholars have used, and, in keeping with suggestions that archaeologies of the contemporary world should be defined by their focus on practice, elucidate how some archaeologies may be seen as more 'contemporary' than others.

The focus on the contemporary world can be thought of as oriented towards a few broad themes or analytics: time, materiality, and self-critical practice. One could include numerous additional items within this list (modernity, ontology, popular culture, etc.) but for the moment the triad of time, materiality, and practice is a useful entry point for this discussion. In critiquing the notion that archaeology is inherently the 'discipline of the spade' (Olsen et al., 2012: 61), archaeologists have drawn attention to how this focus on unearthing things temporally and physically removed from excavators themselves creates a misleading distance between past and present. 
While these arguments have not led to a widespread renunciation of excavation as archaeology's signature methodology (see Harrison, 2011 and responses therein), they have chimed with contemporary archaeology's use of more ethnographic and historical toolkits; about this, more shortly. They have also fuelled criticisms of how archaeology approaches its conception of time as fundamentally progressive and modernist in nature: as something linear, progressing in orderly fashion through distinct periods with minimal overlaps that culminate in the present. Scholars like Yannis Hamilakis (2014), Chris Witmore (2013), Alfredo González-Ruibal (2016, 2018), and others have argued that archaeologists should instead focus on the existence of different kinds of time different cadences inhering in diverse material and biological processes, as well as different cultures' and individuals' experiences of time - that co-exist, overlap, and contradict or transgress time conceived as linear. A focus on the past as contemporary acknowledges these 'pluri-temporal' possibilities, including the potential for aspects of the past to remain active in the present.

In this sense, archaeological approaches to the contemporary world and its temporalities have positioned themselves to elaborate on materiality. Asserting that humans and objects shape one another during the course of their entangled biographies (Miller, 2005), a focus on materiality blurs the distinction between subjects and objects and forces one to confront questions of where to locate agency in these relationships: how much we should accord non-humans (including things and other biota) the ability to shape human consciousness and motility. Archaeological approaches to the contemporary past have sought to expand the temporal remit of materiality by suggesting that we pay attention to how, even while things and people are constantly transforming and shaping one another, they do so while carrying aspects of the past with them (Buchli and Lucas, 2001; Hicks, 2010; Harrison, 2013). That is, 
acknowledging how the material qualities inherent in objects are themselves historical products, composed of textures, memories, and qualities with roots in the past.

These three points - time, materiality, and self-reflection - suggest that an archaeology of the contemporary world is perhaps more about creatively engaging the present than a focus on the contemporary past as a chronological unit (González-Ruibal, 2018). Practically, scholars like Graves-Brown (2000: 7) have suggested that this leads to consideration of how 'we are ourselves part of the world we seek to understand and, rather than seeking to stand aside from society and pontificate on it, we need to be within the process and, albeit critically, allow experience to guide our understanding.'

This leads to a major methodological consideration: where does the researcher situate themselves and their perspective relative to the subject of their enquiry? Unlike traditional archaeology in which the researcher works from a vantage point 'downstream' (i.e. younger than) their subject matter, in exploring the contemporary world the researcher is planted firmly in the same temporal and (sometimes) social context. Ethnography presents itself as suited to the task, given its emphasis on describing 'insider' perspectives on contemporary societies. Graves-Brown's statement just quoted would further offer autoethnography as a possibility, although in African contexts autoethnography is rarely encountered.

Ethnography - especially its use in ethnoarchaeology - has been an important constituent of archaeological practice since the New Archaeology of the 1960s and 1970s sought contemporary analogues to explain past behaviour. Ethnoarchaeology became closely associated with the era of positivist archaeology in the 1970s and 1980s (focused on identifying correlates between modern human behaviour and the archaeological record), but perhaps its most notable early use in Africa was within Ian 
Hodder's (1982) study of Kenyan material culture as actively involved in contemporary meaning-making rather than passively reflecting social order. In its modern formulation ethnoarchaeology uses ethnographic methods like interviews and participant observation alongside archaeological ones like materials analysis to understand how contemporary people engage with material and technology, and 'how they are affected by and interact with the materiality of other living and spiritual entities' (Lyons and Casey, 2016: 609-610). This can sometimes lend itself to interpreting traces of the past, but primarily it focuses on long-term and ethical engagements with living communities and refuses to take for granted that the present is or is not different from the past. Major aims are to "evaluate archaeological theory and methods within the range of known human experience' and promote 'ways of thinking differently about human engagements with the material' (Lyons and Casey, 2016: 610, 612).

Critiques of archaeologies of the contemporary world that borrow from ethnoarchaeological methods have drawn attention to where these have paid insufficient attention to how their work relates to long-term developments in ethnoarchaeological practice, thus failing to appreciate the epistemologies underpinning their work and where the 'archaeology of us' framework jeopardises the ethical situation of contemporary projects. On this last point, Kathryn Fewster (2013) has drawn attention to how one of the tenets of ethnoarchaeology is that the researcher is not the sole interpreter of material culture and technology; this derives from a process of 'slow science' (MacEachern and Cunningham, 2016) involving lengthy collaboration with living communities that allow their expertise and experiences.

Shadreck Chirikure (2016: 694) has raised the question of whether African ethnoarchaeologists drawing on their own life experiences must then have these 
experiences validated by the scholarly community to count them as evidence. This resonates with Olivier Gosselain's (2016) argument that ethnoarchaeology divides the world into non-Western societies suitable for analogy and Western ones that are not. Chirikure highlights the different stakes and standards that apply to 'archaeologies of us' when the 'us' refers to indigenous communities, and further queries how separable ethnoarchaeology (or, indeed, ethnography) is from archaeologies of the contemporary world. That said, African archaeologists are much better represented in the former than the latter, and arguments have been made to take ethnoarchaeology's reflexive as a way to interrogate the traces of archaeology's own practices (Roddick, 2019) and focus on the historicities of non-Western communities contributing ethnoarchaeological knowledge (Lyons and David, 2019). Methodologically, the distinction between ethnoarchaeology and archaeologies of the contemporary world is particularly salient where the latter have not engaged with the issues just described and where they uncritically conflate or combine ethnographic and material culture-focused methodologies; these developed along different trajectories and with different understandings of how data are generated.

Material culture studies as a field emerged in the late 1990s and early 2000s with the focus on the recursive relationship between people and objects outlined above with respect to materiality. Within Africa, associated methodologies were originally ethnographic and historical, seeking to overcome earlier treatments of African objects as art that led to an overstated emphasis on connoisseurship and authenticity. It was in the latter half of the twentieth century that more contextual, anthropological approaches examined the roles of objects in shaping identities and societies within modern African communities, thereby rejecting the notion that African objects and their value could be 
most authoritatively defined by an external art market or art historical community (Hardin and Arnoldi, 1996: 5, 8).

This turn did not reject historical approaches to material culture but largely sought to bridge them with anthropological ones. Studies emerged that featured long-term, ethnographic fieldwork while emphasising an agenda that included indigenous classification schemes and 'forms of knowledge' about objects and technologies, the shifting meanings of objects, and how those meanings could produce modes of exclusion and inclusion (Hardin and Arnoldi, 1966: 11). More recently, and by treating material culture as knowledge that can be used, celebrated, protected, and commodified (Rowlands, 2006: 443), material culture studies in Africa have expanded to consider the roles of objects and technologies in the politics of recognition that characterise the related field of African heritage studies.

While archaeologies of the contemporary world emanating from outside of Africa often combine archaeological methods with those of material culture-oriented studies, this has yet to become common practice in African contexts. There thus remains a distinction on the continent between ethnoarchaeological and material culture studies methodologies, although some recent work suggests that this may be shifting (Derbyshire, 2017).

A focus on the contemporary world also requires asking how this world (or worlds) came to be, and as such often involves recourse to the theories and methodologies used by archaeologists of the historical past. Currently, this encompasses working with 'unofficial' sources like oral histories and considering the 'silences and mentions' produced by diverse bodies of evidence like archives, maps, object collections, excavated materials, surface finds, and others that archaeologists utilised to recover past 
voices. In particular, this demanded a critical focus on how each of these bodies of evidence was produced, and a deep interrogation of the biases in content and archiving practices that such sources entail (see King, 2017 for a review).

Archaeologies of the contemporary world often rely on a similarly eclectic range of materials to provide historical perspective. Nevertheless and outside of Africa, there persists a tension between establishing the historical conditions that produced the modern world and a scepticism that historical materials and frameworks can accommodate the sorts of pluri-temporal perspectives desired by archaeologists of the contemporary (Witmore, 2013; González-Ruibal 2016, 2018). This scepticism stems in part from the suggestion that archaeology too often risks being shunted into historical eras and periods rather than determining its own chronology, and that the sources most common to historical studies (e.g. texts) inevitably lead to these periodisations; a focus on objects allows one to build alternative chronologies. Such views are at odds with recent moves by historians, archaeologists, anthropologists, and art historians within Africa to treat historical materials (including archives) as fundamentally pluri-temporal, related to diverse forms of historical consciousness and epistemologies (see, e.g., Hamilton and Leibhammer, 2016). Not only do archaeologies of the contemporary world need to take cognisance of these moves on the continent, but broader global trends in the study of the contemporary past would benefit from being more alert to contributions from African contexts.

It is worth considering the core concepts, methodologies, and cognate fields underpinning archaeologies of the contemporary world not because they all appear in studies of the recent and contemporary past in Africa. Instead, and given that this is a young sub-field that has yet to gain widespread traction in African contexts, it is useful 
to consider the possible directions and consequences for these research foci and tools in light of prevailing currents within archaeology and related disciplines. Not only do the histories and current directions of those disciplines and their methods have particular trajectories on the continent, but the ethical and epistemological entailments of using or recombining them need to be thought through carefully. This is not only to ensure the sort of multivocality advocated for by many archaeologists, but also to avoid creating a 'sub-disciplinary self-consciousness' premised on a failure to critically examine its specific methodological roots (Fewster, 2013: 28). The result would be the propagation of epistemologies that are flat, lacking in nuance, and reproduce or reaffirm habits of reasoning that had been challenged by earlier scholars in cognate fields.

\section{Excursions in the recent and contemporary past in Africa}

While one could argue that studies in the archaeology of African history (encompassing periods of time in the nineteenth and twentieth century) could justifiably be labelled as the 'recent past', this article is not going to split hairs by drawing boundaries around what is and is not recent. Instead, it is worth focusing on work that either self-identifies as being concerned with the recent and contemporary past and/or that explicitly draws on conversations related to this sub-field elsewhere in the world. While archaeologies of the contemporary world draw on a number of methodologies, all the examples discussed here are heavily ethnographic, although some exist in combination with archaeological methodologies that align them (either explicitly or implicitly) with ethnoarchaeology. This close alignment and overlap raises questions about the intellectual moves that each sub-field is trying to promote and what is gained by their heuristic and practical separation. There is not scope to unpack this here, although it is worth noting that this separation means that African scholars' work is less aligned with archaeologies of the contemporary world. I suggest that readers do not focus overmuch 
on trying to classify these projects primarily anthropological or ethnoarchaeological or other, except to note what these inclinations mean for the sorts of data that are produced and what those data are being asked to do in each case.

Consider, for instance, Sam Derbyshire's $(2017,2018)$ ethnographic examination of temporal consciousness and materiality within Kenya's Turkana region. Derbyshire's work counters longstanding assumptions that nomadic communities in Turkana are largely 'timeless' or lacking a detailed history by not just soliciting oral histories, but by gaining an understanding of how time itself is experienced and imagined. A focus on material culture and its characteristics facilitates this: Derbyshire utilises ethnographic collections of photography from Turkana (located in the Pitt Rivers Museum's archives) as a means of facilitating conversation with interlocutors, and follows 'biographies of various object categories or 'types' over several decades of socio-economic, ecological and political change' (2017: 40, emph orig). Doing so makes it possible to trace 'how histories of production, use and exchange, and the gradually transforming social institutions in which these have been entangled over the years, are immanent and critical forces' in human relationships with material culture, and in how this material culture itself contains a sense of history that keeps the past active in contemporary communities (ibid.; this latter point invokes ideas by Webb Keane). Moreover, by developing this ethnographically-articulated sense of time, historicity, and materiality, Derbyshire both argues for and demonstrates the value of an 'of-the-place epistemology', a concept proposed by John Giblin (2012: 136) and describing a collaborative approach to knowledge production between indigenous communities and researchers. 
In this and other aspects of his methodology, Derbyshire (2017: 37) explicitly does not model his approach on archaeologies of the contemporary past. He draws attention to where these studies often describe an ethnography that avoids long-term observation and encounter (ill-suited to the epistemologies he wants to articulate) and are perhaps too quick to dismiss how the meanings of objects and places are constructed through long-term creative engagements. Derbyshire's research is useful to consider in detail, then, for where it aligns with archaeologies of the contemporary world and where it seeks to challenge these from an Africanist perspective: the sub-field provides useful theoretical orientations concerning the affordances of objects and places (their materialities, social lives, and historicities), but is not completely up to the task of examining the way time is experienced in the present of indigenous communities in Turkana. This demands a particular kind of methodology and ultimately an awareness of how these communities' engagement with the past is best understood as a 'creative engagement with the present' (Harrison 2011, 154).

This last point resonates with work by Alfredo González-Ruibal (2015), which often aligns itself with archaeologies of the contemporary world outside of Africa (his research encompasses South America and Europe) but also includes a conjoined ethnographic and archaeological study of resistance in contemporary communities in the borderlands between Ethiopia, Sudan, and South Sudan. As with Derbyshire, González-Ruibal's An archaeology of resistance (2014) is concerned with understanding how objects and places represent different experiences of time. His archaeology of the present 'studies a multiplicity of times through its materialization in a plurality of things' (2014: 16). González-Ruibal's approach to resistance, then, examines 'how things and memories [...] are mobilized to resist oppression, exactions, or assimilation', especially where resistance draws on memories and historical 
consciousness (2014: 12). González-Ruibal achieves this through a combination of ethnographic work that focuses on a 'thick description' of peoples' relationships to certain categories of material culture, alongside more conventional archaeological techniques (excavation, survey) that highlight how objects can be used to answer back to state desires for control, classification, and regulation.

González-Ruibal is also careful to distinguish his archaeology of the present from ethnoarchaeology, characterising the latter as the study of living societies to gain new insight into ways of interpreting the archaeological record rather than primarily focused on contemporary life $;{ }^{1}$ by contrast, Per Ditlef Fredriksen firmly relates his work to an ethnoarchaeology that is equally concerned with the past and with producing understandings of contemporary livelihoods. Focusing on the materialisation of technological innovations (primarily ceramic) in southern Africa over the last 300 years, Fredriksen's (2011) research has emphasised ethnographic observation and participation with living communities of potters in southern Africa. More recently and in work with Foreman Bandama (Fredriksen and Bandama, 2016), we see this as especially aligned to an archaeology of the present in that it draws attention to how material agency and technological knowledge are both in motion - enacted through repetitive, often taught, activities that take place in centres of domestic life that draw on earlier or longstanding knowledge. In their study of living potting communities in South Africa's Limpopo Province, for instance, Fredriksen and Bandama describe the vulnerabilities of crafting practices in contexts where clay sources are not always accessible and the challenges of translating these practices across workshops and household spaces when inter-generational knowledge networks are disrupted; this discussion is concerned with articulating a form of heritage rather than archaeological analogy with the past, and as such is firmly present-focused. 
Contemporary archaeology in this case entails using archaeological tools like ceramic analysis and ethnography in combination to understand the social processes behind the negotiation of craft knowledge. This description could be applied to numerous other ethnoarchaeological studies that do not primarily identify as archaeologies of the contemporary world. Fredriksen and Bandama's work is notable here because of how it specifically invokes the notion of an 'archaeology of the present' to reference how memory and embodied knowledge do not allow for a neat cleavage between past and present, and to highlight how within this blurry flow of time technical knowledge can become characterised as a form of heritage.

In a related vein, work that often aligns itself with the aims of identifying 'usable pasts' - archaeological knowledge that can address present-day problems (Lane, 2011; Stump, 2013) - argues that treating African technical knowledge as recursively linking the past and present can helpfully muddy the waters between the two in a way that ultimately supports contemporary livelihoods and well-being. Inter-disciplinary research by Matt Davies, Henrietta Moore, and colleagues (combining anthropological, archaeological, and environmental scientific perspectives) examines the matrix of irrigation, agropastoral marketplaces, domestic work, and inter-generational relationships that shape rural economic life in western Kenya, treating this matrix as embedded in longer-term associations with landscape and historical awareness. These associations are facilitated through memory, embodied knowledge, and oral histories (among others), all of which entail an active relationship with the present that makes it impossible to separate modern development imperatives from peoples' past experiences.

As such, Davies and colleagues categorically reject 'synchronic or atemporal' perspectives that fail to grasp this recursivity between 'human agency and ecological 
change' that give rise to 'competing "pseudo-historical" views or environmental narratives (Davies et al., 2014: 488). Instead, they argue for a 'diachronic' view drawing on historical and archaeological perspectives without adhering too rigidly to these disciplinary or temporal divides: history, archaeology, ethnography, and so on represent different tools for recovering different sorts of data, but combine to form an overall picture of a human ecology that emphasises the connections between temporality, technical and environmental knowledge, domestic life, and economy at multiple scales. For instance, in this work Davies and colleagues propose that it is perhaps more useful to consider residents of Marakwet as managing water, rather than irrigation, as water is a more salient actor in shaping household life through time.

This research highlights some notable trends and affordances of the contemporary past in Africa: the potential for landscapes (as an analytical focus or entry point) to offer multi-temporal perspectives; the value of inter-disciplinary work that is aware of its diverse practices and ways of producing knowledge (and the nature of the data that this yields) but still manages to treat temporal boundaries as fluid; and the importance of scholarship that (like Fredriksen and Bandama's) emphasises the recursivity of African knowledge systems, which have too often been balkanised, qualified, or minimised (Mavhunga, 2017).

Moreover, this and other scholarship on usable pasts has sought to highlight where these more nuanced approaches can productively engage with modern planning for development and resilience (Marchant and Lane, 2014; Davies et al., 2016; Petek, 2018). These engagements are essential for the communities to which research pertains and (more self-interestedly) for maintaining archaeology's relevance on the continent (Pikirayi, 2015); I would add that it is worthwhile to include concepts like development 
and resilience and their associated institutions to diachronic scrutiny, examining their own recursive knowledge practices and how these implicate (or misconstrue or minimise) African environments and people.

It is also worth noting that usability in this sense is not limited to ecology or economy, but can also relate to well-being and post-trauma or post-conflict contexts. While this has been less-explored in a specifically contemporary past framework, we can see shades of it in studies examining, for instance, generational legacies of HIV/AIDS and practices of keeping memories of kingship and ancestry active through disruptions caused by colonialism, liberation struggles, and post-independence politico-economic transformations (e.g. Segobye, 2005; Walz, 2009; Schmidt, 2010; Jopela, 2017; Kusimba, 2017).

We can, however, observe an archaeology of the contemporary world at work in postconflict situations in John Giblin's research in Uganda and Kenya, which focuses on recent conflicts such as the Ugandan Northern War and the Rwandan Civil War and Genocide. Writing in 2015 of both previous and future work on this topic, Giblin considers archaeology's role in historicising and memorialising conflict in the Great Lakes region, both in ethical and methodological terms. With respect to the latter, an orientation towards the contemporary past treats archaeology as 'just one co-creative part of a much larger human process of assembling and re-assembling material remains to make meaning in the present' (Giblin, 2015: 126-127), meaning that then creates space for living people to be crucial to understanding how the present and past are entangled. Memory in particular emerges as a conceptual analog to archaeology here, as individuals bring "various traces of the past, as mentally stored codes, 
together in the present during new episodes of remembering and forgetting' (2015: 127).

This then permits an approach combining archaeological surface survey with cocreative, participatory methods: sampling material culture and collecting memories and oral histories associated with the Ugandan internally displaced persons camp at Pabbo; rejecting exploration of archaeology that might be practically available but so sensitive (emotionally, politically) as to render its recovery unethical (Giblin, 2016). Ultimately, argues Giblin, the ethical implications of any archaeological intervention must dictate both investigative and interpretive strategies and, in the rare conflict-related occasion where such strategies are possible, should incorporate storytelling and other forms of memory work that recognise post-conflict communities as co-creators of knowledge about trauma and its aftermath. A contemporary past orientation provides the tools and framework for achieving this while, importantly here, creating a space in which local peoples' knowledge and memories are central to the entire archaeological endeavour.

\section{Critical review of the literature}

Several themes emerge in these excursions into the young but growing body of scholarship on the recent and contemporary past in Africa: an emphasis on foregrounding and taking seriously African knowledge systems, especially diverse experiences of time and materiality; the potential for co-creation of data through relationships between these and Western ways of knowing, and the ethical entailments this brings; mixing methods and keeping sight of the epistemological differences that these entail; and a related awareness (even an anxiety) of the overlap between subdisciplines like ethnoarchaeology and ethnography. Generally absent from or muted in these studies (although included in more global treatments of the contemporary world) 
is a focus on more historical sources and methods (but Davies et al., 2014, Walz, 2009, and Derbyshire, 2017 offer correctives to this), deliberate efforts to render the present 'uncanny', and an 'archaeology of us' framework with a critique or problematisation of this. These trends could be read as a modification of the global scholarship, in which elements of this work are selectively incorporated into approaches in Africa with attention to the use of ethnographic and ethnoarchaeological methods.

They could also be read in part as a response to where other currents of archaeological work on the continent render elements of the contemporary past redundant, confusing, or unnecessary. It is worth reviewing where such overlaps pose either productive complements or questions to be answered as the future of archaeologies of the contemporary world unfolds.

The relationship between the archaeology of the contemporary world and ethnoarchaeology needs particularly careful consideration, attending both to where methods and epistemologies overlap and to where the cleavage between the two has tended to result in work by African scholars being better represented in the latter. Indeed, while ethnoarchaeology has witnessed profound revision and reflection along thse lines, the archaeology of the contemporary world - globally and in Africa - has yet to do so, perhaps because of its relative youth. Future work on the latter will need to grapple critically with the reasons for this and their consequences: what epistemic perspectives and histories does this heuristic and practical split foreground or elide? Do archaeologies of the contemporary world offer a fresh start, as opposed to 'an umpteenth salvage' of ethnoarchaeology (Gosselain, 2016: 215)? Or can we, as Fredriksen and Bandama seem to suggest, merge the two sub-fields in positing that embodied knowledge does not allow for a clean break between past and present, which 
would also foreground the political valences of an expressly present-oriented archaeology?

Relatedly, 'if the past is always encompassed within the present', then one element connecting 'contemporary archaeology with the discussions of material memory and the politics of the past' is the acknowledgement that 'the efficacy and the political importance of material traces often derive from the fact that they enact different times simultaneously' (Harrison and Breithoff, 2017: 209). Put differently, objects do powerful work on memory and politics by dint of their ability to evoke multiple experiences of or ideas about the past. This is an idea that resonates strongly with heritage studies, which emphasise how traces of the past (remembered, performed, debated, or materialised) have an impact on the present. While this is a diverse and complex field, here we should note that they are especially characterised by the notions of value that the concept of heritage mobilises, how heritage practices implicate memory and time, and the particular efficacies that heritage assets have in political and commercial spheres.

If heritage is a category that is determined largely through value (i.e. something counts as heritage if it can demonstrate a particular quality or quantity of significance) (Lafrenz Samuels, 2008, 2018), then the power to put limits or qualifications on that value, to profit from or conserve it is crucial to understanding what heritage can do (Rowlands and De Jong, 2007: 13-16). This sort of power, whether held by governments, civil society, conservation organisations, or international consultants influences the ways in which different publics are encouraged to remember or envision the past and its legacies. Experiences of the past in the present, then, are always multiple and always entangled with different forms of power and authority. One could argue that heritage 
studies make a focus on this intersection of time and power more explicit than contemporary archaeology, and include within their disciplinary ambit an exhortation to devote equal attention to exploring this power and the temporalities with which it is concerned (cf. Ndoro, 2001; Coombes et al., 2014; Fouéré and Hughes, 2015; Giblin, 2018)

Heritage studies may also prove a more relevant or useful orientation than the archaeology of the contemporary where the efficacies afforded to heritage are stronger, in terms of political and commercial power. Heritage industries (in Africa and globally) have emerged as significant forces for mobilising financial, social, and developmental forces (Comaroff and Comaroff, 2009; Basu and Modest, 2014; Coombe and Weiss, 2015). Similarly, heritage politics have become an arena for observing how global, national, and local interests in the past intersect (e.g. Kirkwood, 2013; Basu and Zetterström-Sharp, 2014; Josse-Durand, 2015, 2018); this arena has proven to be a vibrant site of protest and the performance of state power, as one can see from acts of iconoclasm like the \#RhodesMustFall movement and the creation of liberation heritage sites across the continent (Nyamnjoh, 2016; Jopela, 2017). Thus, heritage scholarship not only seeks to interrogate this entangled web of past and present, but also to actively contribute to or impact upon that web through increased imperatives to produce work that is 'useful' and relevant at these intersections of development, politics, and so on. While the contributions of this scholarship in other spheres and industries is certainly debatable in some cases, this impactful orientation is often either absent from contemporary archaeology or focused on a more local, constrained scale.

Relatedly, archaeologies of the contemporary world have roots in a critique of capitalism and modernity that bears closer scrutiny for how these critiques resonate 
with (or fail to) contexts on the African continent. As post-modern critical interventions have interrogated the epistemologies and assumed inevitability of the modern era, perspectives from archaeology have argued that modernity (at least in its later stages) can be characterised as a 'fragile and unfinished project' related to the speed and extent with which material culture, capitalism, media, technology, and leisure time proliferate (González-Ruibal, 2008). However, the trajectories outlined for capitalism and latestage or super-modernity above cannot be assumed for African contexts but must be anchored in longer-term critical understandings of the histories of capitalism, mercantilism, etc. on the continent, both within trans-oceanic systems and within the continental interior. Derbyshire's (2018) work offers a useful way forward for exploring this.

If a signature part of contemporary archaeology's agenda is working across multiple temporalities, popular culture studies (which often draw from ethnographic methodologies and focus on performance and media) are also notable venues for considering this theme. This is a huge body of literature that cannot be discussed fully here, but worthy of note are observations by Birgit Meyer (made with reference to narrative film in Ghana) that certain media afford an understanding of popular imaginations that actively comment on 'modernity's attractions and malcontents' (Meyer, 1999: 111) and move beyond 'reified contrasts' between a backward-looking traditional past and a progressivist future (Meyer, 2010: 10). In considering where Ghanaian epic histories and nationalism-inflected 'roots' stories address legacies of the past amidst modern contexts that are also imbricated with Pentecostalism, consumerism, and urbanisation, Meyer draws attention both to a wider range of media in which experiences of time reside and to an important emphasis on performance and reception. 
Popular culture studies, then, direct us to a wide range of media and actors that are implicated in combining, contravening, and challenging different temporalities. Archaeologies of the contemporary world in Europe and North America have engaged enthusiastically with popular culture products; if similar efforts are to be reproduced in Africa, they should take cognisance not only of the different spheres of lived experience that contribute to these media (religion, consumerism, gender, etc.) but also the diverse and often subtle ways in which knowledge about the past is implicated in these media. Following Meyer, many popular media have already moved beyond crude distinctions between backward- and forward-looking attitudes; the onus then falls on researchers to pay close attention to how these conversations play out, via methodologies like (as Meyer and others suggest) ethnography.

Archaeologies of the contemporary world in Africa therefore offer exciting theoretical lenses and applications, of which we are now seeing only the vanguard. The progression of this sub-field on the continent will be heavily influenced by how practitioners adapt its ethics and methods to the particulars of new regional contexts. Doing so in concert with other cognate fields holds potential for enriching both data and archaeological practice, if scholars orient themselves inter-disciplinarily.

\section{Further reading}

Victor Buchli and Gavin Lucas, eds., Archaeologies of the Contemporary Past (New York: Routledge).

Matthew I.J. Davies, Timothy K. Kipruto, and Henrietta L. Moore, 'Revisiting the Irrigated Agricultural Landscape of the Marakwet, Kenya: Tracing Local Technology and Knowledge over the Recent Past,' Azania: Archaeological Research in Africa 49 (2014): 486-523.

Alfredo González-Ruibal, An Archaeology of Resistance: Materiality and Time in an African Borderland (Lanham, MD: Rowman \& Littlefield, 2014).

Alfredo González-Ruibal, An Archaeology of the Contemporary Era (London: Routledge, 2018). 
Paul Graves-Brown, Rodney Harrison, and Angela Piccini, eds., Oxford Handbook of the Archaeology of the Contemporary World (Oxford: Oxford University Press, 2013).

Rodney Harrison and Esther Breithoff, 'Archaeologies of the Contemporary World', Annual Review of Archaeology 46 (2017): 203-221.

Rodney Harrison and John Schofield, After Modernity: Archaeological Approaches to the Contemporary Past (Oxford: Oxford University Press, 2010).

\section{Notes}

${ }^{1}$ González-Ruibal $(2006,2016)$ sees this as fundamentally a process of analogical reasoning, while scholars like Lyons and Casey (2016) maintain that many ethnoarchaeologists are firmly focused on the present. For perspectives on how all archaeology is fundamentally analogical, see McGranaghan, 2017.

\section{References}

Basu, P., \& Modest, W. (2014). Museums, heritage and international development: A critical conversation. In P. Basu \& W. Modest (Eds.), Museums, heritage and international development (pp. 1-32). New York: Routledge.

Basu, P., \& Zetterström-Sharp, J. (2014). Complicating culture for development: Negotiating 'dysfunctional heritage' in Sierra Leone. In P. Basu \& W. Modest (Eds.), Museums, heritage and international development (pp. 56-82). New York: Routledge.

Buchli, V., \& Lucas, G. (2001). The absent present: Archaeologies of the contemporary past. In V. Buchli \& G. Lucas (Eds.), Archaeologies of the contemporary past (pp. 3-18). New York: Routledge.

Chirikure, S. (2016). 'Ethno' plus 'archaeology': What's in there for Africa(ns)? World Archaeology 48 (5), 693-699.

Chirikure, S., Manyanga, M., Ndoro, W., \& Pwiti, G. (2010). Unfulfilled promises? Heritage management and community participation at some of Africa's cultural heritage sites. International Journal of Heritage Studies 16 (1-2), 30-44.

Comaroff, J.L., \& Comaroff, J. (2009). Ethnicity, inc. Chicago: University of Chicago Press.

Coombe, R.J., \& Weiss, L.M. (2015). Neoliberalism, heritage regimes, and cultural rights. In L. Meskell (Ed.), Global heritage: A reader (pp. 43-69). Malden, MA: John Wiley \& Sons.

Coombes, A., Hughes, L., \& Karega-Munene (Eds.). (2014). Managing heritage, making peace: History, identity and memory in contemporary Kenya. London: I.B. Tauris.

Croucher, S., \& Weiss, L.M. (Eds.). (2011). The archaeology of capitalism in colonial contexts: Postcolonial historical archaeologies. New York: Springer. 
Cunningham, J.J., \& MacEachern, S. (2016). Ethnoarchaeology as slow science. World Archaeology 48 (5), 628-641.

Davies, M.I.J., Kipruto, T.K., \& Moore, H.L. (2014). Revisiting the irrigated agricultural landscape of the Marakwet, Kenya: Tracing local technology and knowledge over the recent past. Azania: Archaeological Research in Africa 49 (4), 486-523.

Davies, M.I.J., Folorunso, C.A., Kipruto, T.K., Nkirote M'Mbogori, F., Moore, H.L., Orijemie, E.A., \& Schoeman, A. (2016). The 'useable' archaeology of African farming systems. In K. Sadr, A. Esterhuysen, and C. Sievers (Eds.), African archaeology without frontiers: Papers from the 2014 PanAfrican Archaeological Association Congress (pp. 1-31). Johannesburg: Wits University Press.

Dawdy, S.L. (2010). Clockpunk archaeology and the ruins of modernity. Current Anthropology 51 (6), 761-793.

Derbyshire, S.F. (2017). Trade, development and resilience: An archaeology of contemporary livelihoods in Turkana, northern Kenya. DPhil diss., University of Oxford.

Derbyshire, S.F. (2018). Trade, development and destitution: A material culture history of fishing on the western shore of Lake Turkana, northern Kenya. African Studies 78 (3), 324-346.

Fewster, K. (2013). The relationship between ethnoarchaeology and archaeologies of the contemporary past: A historical investigation. In P. Graves-Brown, R. Harrison, \& A. Piccini (Eds.), Oxford Handbook of the Archaeology of the Contemporary World (pp. 27-39). Oxford: Oxford University Press.

Fouéré, M.A., \& Hughes, L. (2015). Heritage and memory in East Africa today: A review of recent developments in cultural heritage research and memory studies. Azania: Archaeological Research in Africa 50 (4), 542-558.

Fredriksen, P.D. (2011). When knowledges meet: Engagements with clay and soil in southern Africa. Journal of Social Archaeology 11 (3), 283-310.

Fredriksen, P.D., \& Bandama, F. (2016). The mobility of memory: Space/knowledge dynamics in rural potting workshops in Limpopo Province, South Africa. Azania: Archaeological Research in Africa 51 (4), 489-506.

Giblin, J. (2012). Decolonial challenges and post-genocide archaeological politics in Rwanda. Public Archaeology 11, 123-143.

Giblin, J. (2015). Towards an archaeology of recent conflict in western Great Lakes Africa. Journal of Conflict Archaeology 10 (2), 123-146.

Giblin, J. (2016). Can, door, heritage. In S. Brown, A. Clarke, \& U. Frederick (Eds.), Object stories: Artifacts and archaeologists. London: Routledge.

Giblin, J. (2018). Heritage and the use of the past in East Africa. In T. Spear (Ed.), Oxford Research Encyclopedia of African History. 
González-Ruibal, A. (2006). El giro postcolonial: Hacia una etnoarqueología crítica. In A. Vila (Ed.), Etnoarqueología de la prehistoria: Más allá de la analogía (pp. 4159). Madrid: CSIC.

González-Ruibal, A. (2008). Time to destroy: An archaeology of supermodernity. Current Anthropology 49 (2), 247-279.

González-Ruibal, A. (2014). An archaeology of resistance: Materiality and time in an African borderland. Lanham, MD: Rowman \& Littlefield.

González-Ruibal, A. (2016). Ethnoarchaeology or simply archaeology? World Archaeology 48 (5), 687-692.

González-Ruibal, A. (2018). An archaeology of the contemporary era. London: Routledge.

Gosselain, O.P. (2016). To hell with ethnoarchaeology! Archaeological Dialogues 23 (2), 215-228.

Gould, R.A., \& Schiffer, M.B. (Eds.). (1981). Modern material culture: The archaeology of us. New York: Plenum Press.

Graves-Brown, P. (2000). Introduction. In P. Graves-Brown (Ed.), Matter, materiality and modern culture (pp. 1-9). London: Routledge.

Graves-Brown, P., Harrison, R., \& Piccini, A. (2013). Introduction. In P. GravesBrown, R. Harrison, \& A. Piccini (Eds.), Oxford Handbook of the Archaeology of the Contemporary World (pp. 1-23). Oxford: Oxford University Press.

Hamilakis, Y. (2014). Archaeology and the senses: Human experience, memory, and affect. Cambridge: Cambridge University Press.

Hamilton, C., \& Leibhammer, N. (Eds.). (2016). Tribing and untribing the archive: Critical enquiry into the traces of the Thukela-Mzimkhulu region from the Early Iron Age until c. 1910. Pietermaritzburg: UKZN Press.

Hardin, K.L., \& Arnoldi, M.J. (1996). Introduction: Efficacy and objects. In M.J. Arnoldi, C.M. Geary, \& K.L. Hardin (Eds.), African material culture (pp. 1-28). Bloomington: Indiana University Press.

Harrison, R. (2011). Surface assemblages: Towards an archaeology in and of the present. Archaeological Dialogues 18 (2), 141-161.

Harrison, R. (2013). Forgetting to remember, remembering to forget: Late moder heritage practices, sustainability and the 'crisis' of accumulation of the past.

International Journal of Heritage Studies 19, 579-595.

Harrison, R., \& Breithoff, E. (2017). Archaeologies of the contemporary world. Annual Review of Anthropology 46, 203-221.

Harrison, R., \& Schofield, J. (2010). After modernity: Archaeological approaches to the contemporary past. Oxford: Oxford University Press. 
Hicks, D. (2010). The material-cultural turn: Event and effect. In D. Hicks and M.C. Beaudry (Eds.), Oxford Handbook of Material Culture Studies (pp. 25-98). Oxford: Oxford University Press.

Hodder, I. (1982). Symbols in action: Ethnoarchaeological studies of material culture. Cambridge: Cambridge University Press.

Holtorf, C. (2007). Archaeology is a brand! The meaning of archaeology in contemporary popular culture. Walnut Creek, CA: Left Coast Press.

Jopela, A.P. de J. (2017). The politics of liberation heritage in postcolonial southern Africa with special reference to Mozambique. PhD diss, University of the Witwatersrand.

Josse-Durand, C. (2015). La musée Konso au coeur de l'arène: Quand les courtiers en développement (re)dessinent les contours du champ politique éthiopien. EchoGéo 31, $1-23$.

Josse-Durand, C. (2018). The political role of 'cultural entrepreneurs' in Kenya: Claiming recognition through the memorialisation of Koitalel Samoei and Nandi heritage. African Studies 77 (2), 257-273.

King, R. (2017). Primary historical sources in archaeology: Methods. In T. Spear (Ed.), Oxford research encyclopedia of African history. Accessed 12 August 2019, https://oxfordre.com/africanhistory/view/10.1093/acrefore/9780190277734.001.0001/ acrefore-9780190277734-e-214.

Kirkwood, M.L. (2013). Post-independence architecture through North Korean modes: Namibian commissions of the Mansudae Overseas Project. In G. Salami \& M.B. Visonà (Eds.), A companion to modern African art (pp. 548-571). Oxford: John Wiley \& Sons.

Kusimba, C.W. (2017). Community archaeology and heritage in coastal and western Kenya. Journal of Community Archaeology and Heritage 4 (3), 218-228.

Lafrenz Samuels, K. (2008). Value and significance in archaeology. Archaeological Dialogues 15 (1), 71-97.

Lafrenz Samuels, K. (2018). Mobilizing heritage: Anthropological practice and transnational prospects. Gainesville: University of Florida Press.

Lane, P. (2011). Possibilities for a postcolonial archaeology in sub-Saharan Africa: Indigenous and usable pasts. World Archaeology 43 (1), 7-25.

Lane, P., \& MacDonald, K. (Eds.). (2011). Slavery in Africa: Archaeology and memory. Oxford: Oxford University Press.

Lyons, D., \& Casey, J. (2016). It's a material world: The critical and on-going value of ethnoarchaeology in understanding variation, change and materiality. World Archaeology 48 (5), 609-627. 
Lyons, D., \& David, N. (2019). To hell with ethnoarchaeology ... and back! Ethnoarchaeology 11 (2), 99-133.

Marchant, R., \& Lane, P. (2014). Past perspectives for the future: Foundations for sustainable development in East Africa. Journal of Archaeological Science 51, 12-21.

Mavhunga, C.C. (2017). Introduction: What do science, technology, and innovation mean from Africa?. In C.C. Mavhunga (Ed.), What do science, technology, and innovation mean from Africa? (pp. 1-27). Boston: MIT Press.

McGranaghan, M. (2017). Ethnographic analogy in archaeology: Methodological insights from southern Africa. In T. Spear (Ed.), Oxford research encyclopedia of African history. Accessed 12 August 2019, https://oxfordre.com/africanhistory/view/10.1093/acrefore/9780190277734.001.0001/ acrefore-9780190277734-e-213.

Meyer, B. (1999). Popular Ghanaian cinema and 'African heritage'. Africa Today 46 (2), 93-114.

Meyer, B. (2010). 'Tradition and colour at its best': 'Tradition' and 'heritage' in Ghanaian video-movies. Journal of African Cultural Studies 22 (1), 7-23.

Miller, D. (Ed.). (2005). Materiality. Durham: Duke University Press.

Mire, S. (2007). Preserving knowledge not objects: A Somali perspective for heritage management and archaeological research. African Archaeological Review 24 (3-4), 49-71.

Monroe, J.C., \& Ogundiran, A. (Eds.). (2012). Power and landscape in Atlantic West Africa: Archaeological perspectives. Cambridge: Cambridge University Press.

Ndoro, W. (2001). Your monument, our shrine: The preservation of Great Zimbabwe. $\mathrm{PhD}$ diss, Uppsala University.

Nyamnjoh, F.B. (2016). \#RhodesMustFall: Nibbling at resilient colonialism in South Africa. Bamenda: Langaa Research \& Publishing.

Olsen, B. \& Pétursdóttir, P. (Eds.). (2014). Ruin memories: Materialities, aesthetics and the archaeology of the recent past. Abingdon: Routledge.

Olsen, B., Shanks, M., Webmoor, T., \& Witmore, C. (2012). Archaeology: The discipline of things. Berkeley: University of California Press.

Petek, N. (2018). Archaeological perspectives on risk and community resilience in the Baringo lowlands, Kenya. PhD diss, Uppsala University.

Peterson, D., Gavua, K., \& Rassool, C. (Eds.). (2015). The politics of heritage in Africa: Economies, histories, and infrastructures. New York: Cambridge University Press.

Pikirayi, I. (2016). The future of archaeology in Africa. Antiquity 89 (345), 531-541. 
Roddick, A. (2019). Archaeologies of the present and sedimented futures: Reflections from Lake Titicaca, Bolivia. Journal of Contemporary Archaeology 6 (1), 101-119.

Rowlands, M. (2006). Introduction: Presentation and politics. In C. Tilley, W. Keane, S. Küchler, M. Rowlands, and P. Spyer (Eds.), Handbook of material culture (pp. 443-445). London: Sage.

Rowlands, M. \& De Jong, F. (2007). Reconsidering heritage and memory. In F. De Jong and M. Rowlands (Eds.), Reclaiming heritage: Alternative imaginaries of memory in West Africa (pp. 13-29. London: Routledge.

Schmidt, P.R. (2010). Social memory and trauma in northwestern Tanzania: Organic, spontaneous community collaboration. Journal of Social Archaeology 10 (2), 255279.

Schmidt, P.R. \& Pikirayi, I. (Eds.). (2016). Community archaeology and heritage in Africa: Decolonizing practice. London: Routledge.

Segobye, A.K. (2005). Weaving fragments of the past for a united Africa: Reflections on the place of African archaeology in the development of the continent in the $21 \mathrm{st}$ century. South African Archaeological Bulletin 60 (182), 79-83.

Stahl, A.B. (2009). The archaeology of African history. International Journal of African Historical Studies 42 (2), 241-255.

Stump, D. (2013). On applied archaeology, indigenous knowledge, and the usable past. Current Anthropology 54 (3), 268-298.

Walz, J. (2009). Archaeologies of disenchantment. In P.R. Schmidt (Ed.), Postcolonial archaeologies in Africa (pp. 21-38). Santa Fe: School of Advanced Research.

Weiss, L.M. (2014). Informal settlements and urban heritage landscapes in South Africa. Journal of Social Archaeology 14 (1), 3-25.

Witmore, C. (2013). Which archaeology? A question of chronopolitics. In A. González-Ruibal (Ed.), Reclaiming archaeology: Beyond the tropes of modernity (pp. 130-144). Abingdon: Routledge. 